\title{
型でと埋没法による一塊鋳造物永久固定法
}

\author{
細田 裕 康*, 原耕 二** \\ *新潟大学歯学部歯科保存学第一教室 \\ $* *$ 新潟大学歯学部歯科保存学第二教室
}

\section{One-Piece Cast Permanent Splint using a Die-Investing Technic}

\author{
Hiroyasu HOSODA * and Kohji HARA ** \\ * Department of Operative Dentistry, Niigata University School of Dentistry. \\ ** Department of Periodontology and Endodontics, Niigata University School of Dentistry.
}

A system of using a new refractory die material was introduced to fabricate a permanent splint for mobile teeth with the indirect method and one-piece casting.

This technic was clinically applied for three female patient mouth stabilizations and has produced favorable results.

Far less time, labor and skill than other technics are required by this die-investing technic.

\section{ま えがき}

歯周病療法の一つとして行われる永久固定法は, 他の 療法によって病変は改善されたがな预歯牙の動摇によっ てその局所の安静が保持されない場合に対し，その部の 負担を軽減し，さらに病変を治瘾にまで導く方法であ る。これまでの固定装置は主として, これら個々の窝洞 について直接または間接法により蠟型を作り, 出来た 鋳造物をろう着連結することによって作られていた。 $\operatorname{Rubin}^{1)}$, 西村 ${ }^{2)}$, 総山 ${ }^{3 \sim 5}$ )らはろう着法よりも一塊鋳造方 式の優位性を実証しており，なかでも総山はアルジネー 卜間接法ならびに精密インレー法の研究を基盤とした一 連の鋳造体系を作り，単純インレーは勿論のことブリッ ジや固定装置までも一塊鋳造によって製作する方法を確 立した。

最近, 真坂6) はリン酸塩系埋没材を使用しての一塊鋳 造橋義歯の精度を報告している。

また著者の一人, 細田7) は試作の模型兼用埋没材を用 いて実験し，型ごと埋没法により作られた一塊鋳造橋義
歯の精度の優秀性を立証している。

“型ごと埋没法”とは従来の蠟型埋没法とは異なり, 印象中に埋没材を入れて耐火性模型を作り，その上で蠟 型を調製し, その模型とともに埋没し，鋳造する方式で ある。

模型上の蠟型を抽出することなくそのまま模型ごとに 埋没し，鋳造のプロセスに持ち込むことが出来ればワッ クスの取り扱いや埋没の操法などに特別の考慮を払う必 要もなくなり狂いを増大寸る可能性も除外出来る。

かような観点から，23歳，女性の左下顎臼歯部，30 歳, 女性の左上顎臼歯部および 32 歳女性, 下顎前歯部 における動摇歯固定のために型ごと埋没法を用いて一塊 鋳造連結物を施し, 咀嚼機能の回復改善に努めた。その 技法の概要と固定後の経過について報告し, 大方の御批 判を仰ぎたい。

$$
\text { 症例 }
$$

症例 $1: \square, 23$ 歳, 女性 固定部位 : 4567 


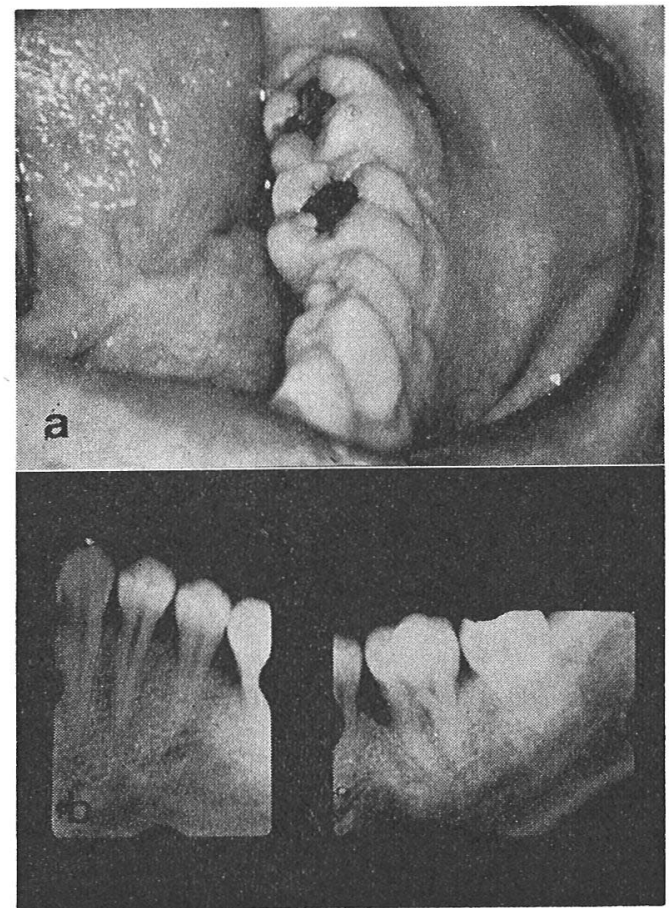

図 1 症例 1 の固定前の口腔内写真(a)とX 線写真(b)

表 1 使用された型ごと埋没材の性能

\begin{tabular}{|c|c|c|c|c|}
\hline & \multicolumn{4}{|c|}{ 压維搔さ $\left(\mathrm{Kg} / \mathrm{cm}^{2}\right)$} \\
\hline & 練和 11 㝍開後 & 3時開後 & 24 洔間行 & 加蓺後 \\
\hline 沘液比 0.24 & 145 & 209 & 527 & 172 \\
\hline 泚水比 0.30 & 98 & 118 & - & 43 \\
\hline
\end{tabular}

\begin{tabular}{|c|c|c|c|c|}
\hline & \multirow{2}{*}{ 谈文結侍寺間 } & \multicolumn{3}{|c|}{ 欵脤量 $(\%)$} \\
\hline & & 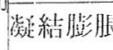 & 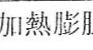 & 総合膨腿 \\
\hline 混液比 0.24 & 13 分 & 1. 24 & 0.51 & 1. 75 \\
\hline 混水此 0.30 & 16 分 & 0.31 & 0.34 & 0.65 \\
\hline
\end{tabular}

\section{固定前の所見}

(1) 臨床的所見（図 1, a)

歯肉の炎症は Gingival Index によれば $0 \sim 1 の$ 範囲 を示し極めて軽度である。歯肉形態は歯間部で blunted 形, $\sqrt{6}$ の辺縁部に recessed 形がみられ, 共に退縮して いる。歯周ポケットの深さは $2 \mathrm{~mm}$ 以内の正常の範囲 内にある。付着歯肉約 $2 \mathrm{~mm}$ の幅で存在し, 臼歯部 としては平均的值を示している。歯の動摇は, 5 が軽度 の動摇を示すほかは，他の骨植状態は良好である。

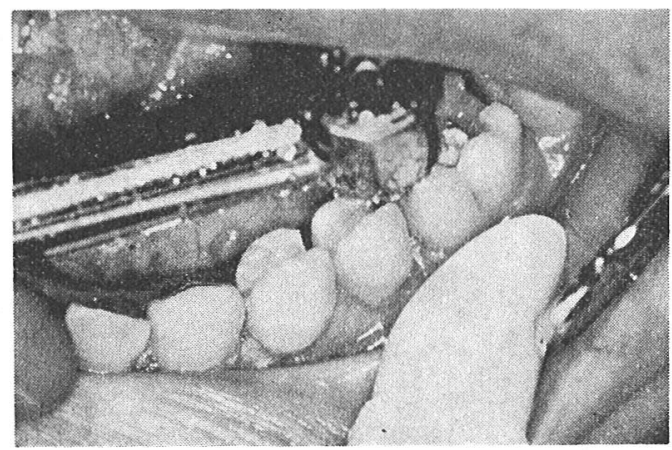

図 2 スライスタイプの MOD 窩洞形成

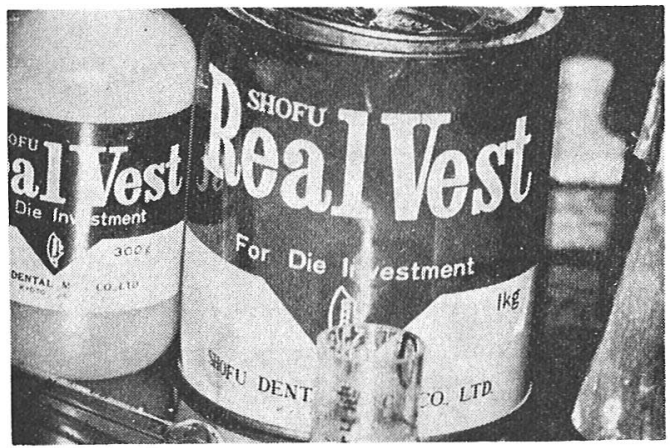

図 3 使用された“型ごと埋没”材

(2) X線所見（図 1， b)

「6の近心側に約 $20 \%$ の垂直性骨吸収がみられるほか は，平均 $10 \%$ の軽度な水平性骨吸収がみられる。歯根 周囲の変化, 寸なわち，白線の消失或は歯根膜腔の拡大 はみられず，咬合は異常なしと判断した。

固定装置のための技法

(1) 裔洞形成

Slice Type の MOD 裔洞を採用し，隣接面には側室 を形成すること避け，半円縦溝のみを形成し，窩洞形 成を単純化した（図 2 )。

(2) 模型兼用埋没材と模型調製

模型兼用埋没材，以わゆる “型ごと埋没材” として松 風 Real Vest（図 3，松風陶歯 K.K. Batch No.6) が 用いられた。その性能は表 1 に示されるごとくである。 本材料慔型用には付属の專用 Colloidal Silica 溶液で 練和し，埋没用としては水で練和するよう指示されてい る。

通法のごとく，歯肉圧排，咬合印記を行っておき，印 象採得を行う。

印象はラバベースまたはシリコン印象材による従来か らの一回印象が適当である。 


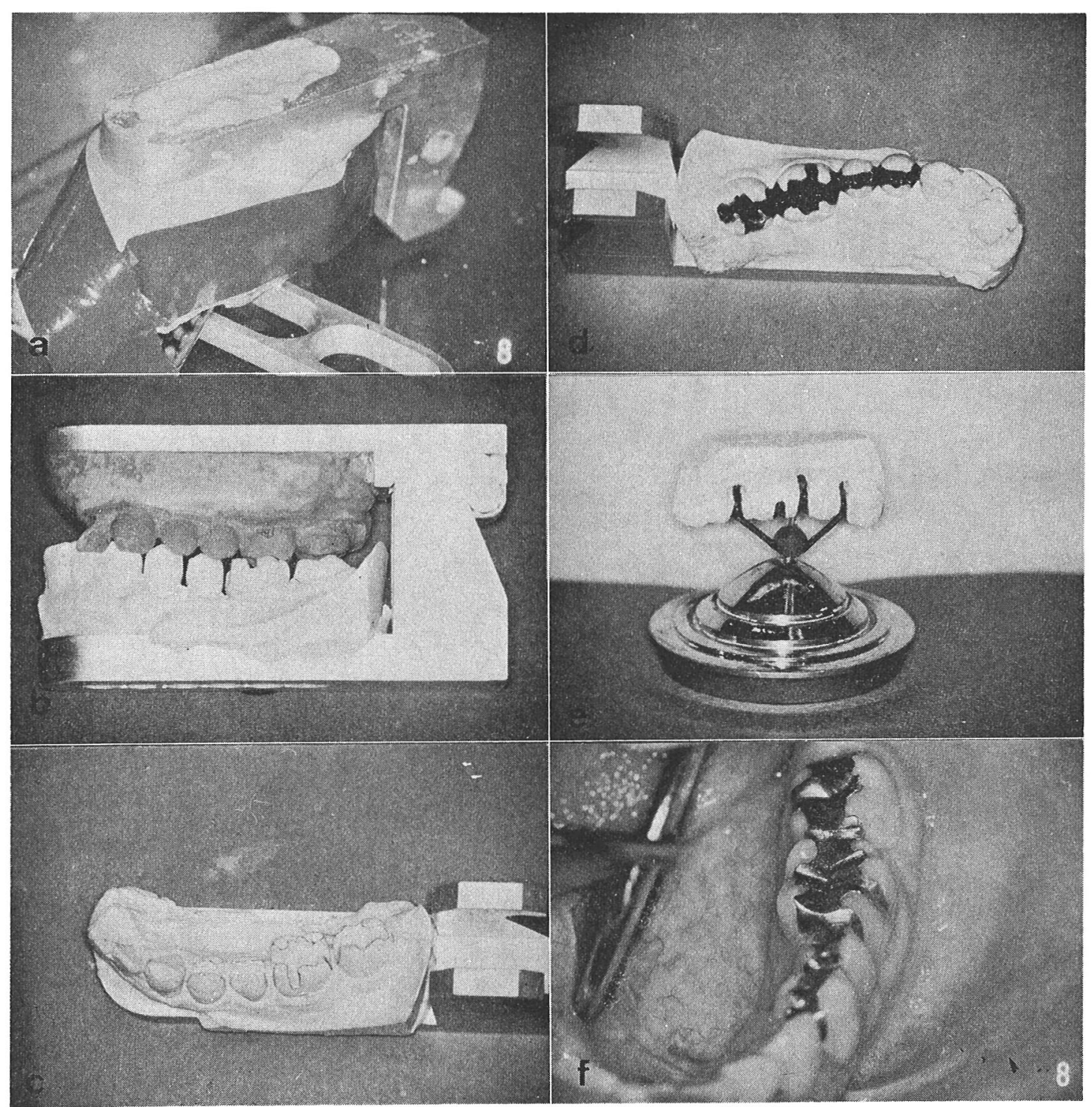

図 4 技法の概 略

\section{a. 咬合器付着 \\ b. 咬合模型 \\ c. 蠟形成準備}

口腔より印象を取り出す 1 分前くらいに，模型材を指 定混液比 0.24 を用いて専用液で練和し, 撤去後直ちに 注大しておけば，狂いの少ない模型が出来る。

専用液で練和された泥状物は稠度が高いので, 練和泥 中の気泡をよく脱泡し, 空気の混入しないように印象内 に注入することが望ましい。また，この練和泥は流れ易 いので, 印象周囲にビニールテープを巻きつけ, 練和泥 の盛り上げを容易にすることである。
d. 蠟 型
e. 模型ごと円錐台植立
$\mathrm{f}$. 装着完成

印象材への模型材の注入を終わって直ちに同じ練和泥 を用いて咬合器に付着する(図 $4, a$ )。

硬化した模型を印象から撤去する時期は注入後 2 3 時間の時期が適当である。この時期になれば，模型材は 撤去に危険のない硬さとなり，しかも模型の歯肉圧排部 などの修正がやり易い。

印象より取り出された模型上に㗳合印象を正置し，石 こうを流して対合歯部を取りつける。これで咬合模型が 


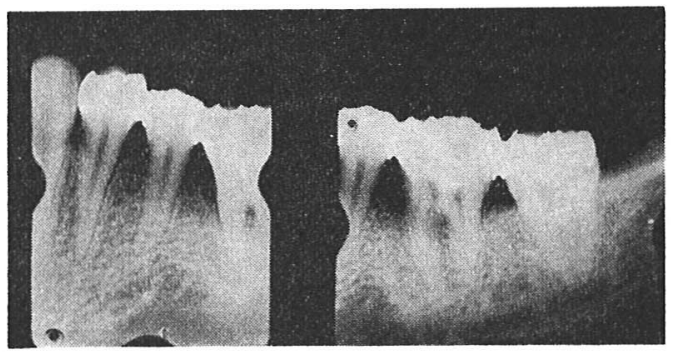

図 5 症例 1 の術後 6 力月のXX線写真

完成する(図 4, b )。

(3) 蠟形 成

出来を模型は盆洞相互の位置関係を狂わせないために 分割することを避少す。分割しない模型では, 各窩洞歯 の歯頸緣の蠟形成が困難なので, 歯頸下部を球型バー でえぐり，辺縁形成の行ない易いようにしておくとよ い。

窩洞外形を鉛筆で描き，签形成に入る(図 4, c)。蠟 形成には間接法または直按法用のインレーワックスを用 い, 溶けたワックスをそのまま窩洞に盛り上げ, 蠟形を 完成する (図 $4, d$ )。この際, 特別の注意を必要としな w。

\section{（4） 埋没・鋳造}

埋没するために, 蠟形成した部分は模型ごと切り出 し, これを水中に 20 乃至 30 分間浸漬し, 円錐台に植立 する(図 4,e )。これをリング内に混水比 0.30 で練和 した模型兼用埋没材料で埋没する。

通法のごとくワックスを焼燼し, $650^{\circ} \mathrm{C}$ 前後の加熱温 度で鋳造を行う。

(5) 完 成

試適, 研磨の後にセメント合着し, 固定を完了する (図 4,f)。

固定 6 力月経過後の所見

X線所見（図 5 ) のみが得られた。これによると固定 前約 $20 \%$ の垂直性骨吸収がみられた 6 の近心部では, 骨の再生がおこり且つ菌槽頂辺縁の明膫化もみられた。 また, 歯根周囲の変化はなく, 歯槽硬線および歯根膜腔 は正常像を示す。以上の所見から, 現在までのところ経 過は極めて良好と判断された。

\section{症例 $2: \square, 30$ 歳, 女性}

固定部位 : $\mid 4567$

\section{固定前の診査}

(1) 臨床的所見 (図 6,a)

歯肉の炎症怯 Gingival Index が0〜1の範囲にあっ て極めて軽度である。歯肉の形態は歯間部で blunted



図 6 症例 2 の固定前の口腔内写真(a)とX線 写真 $(b)$

型, 辺縁部では recessed 型で共に退縮している。歯周 ポケットの深さは $8 \mathrm{~mm}$ を示す樑い杢の類側遠心部ポ ケットを除き, 他忙 $2 \mathrm{~mm}$ 以内の正常範囲にある。付 着歯肉は 2 3 $\mathrm{mm}$ の幅で存在し, 歯槽骨吸収の程度に くらべ，且歯部としては比較的幅の広い層をなしてい る。

歯の動摇は向に軽度な動摇が見られるが，他の歯牙の 骨植状態は良好である。

(2) X線所見 (図 6, b )

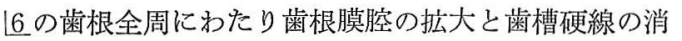
失がみられる。またの近心部ではかなり強い垂直性の 吸収がタられる。

なお，6は知覚過敏のため抜飽処置が施され，17は感 染根管治療が行われている。

固定装置の製作

|67を固定するにあたり，|45を含めての固定装置を計 画し，| 45 を便宜的に抜髄することにした。

䆟洞はすべて Coverage Type とし，巡のみは定型的 な前装 crown, 1567 は窩縁が歯肉縁に達しないように 留意した (図 7,a)。窩洞形成後の印象气の他は症例 1 と同様である。形成歯の暫間的固定は是非とも必要で, ZOE セメントからなる Surgical pack で形成歯を連結 

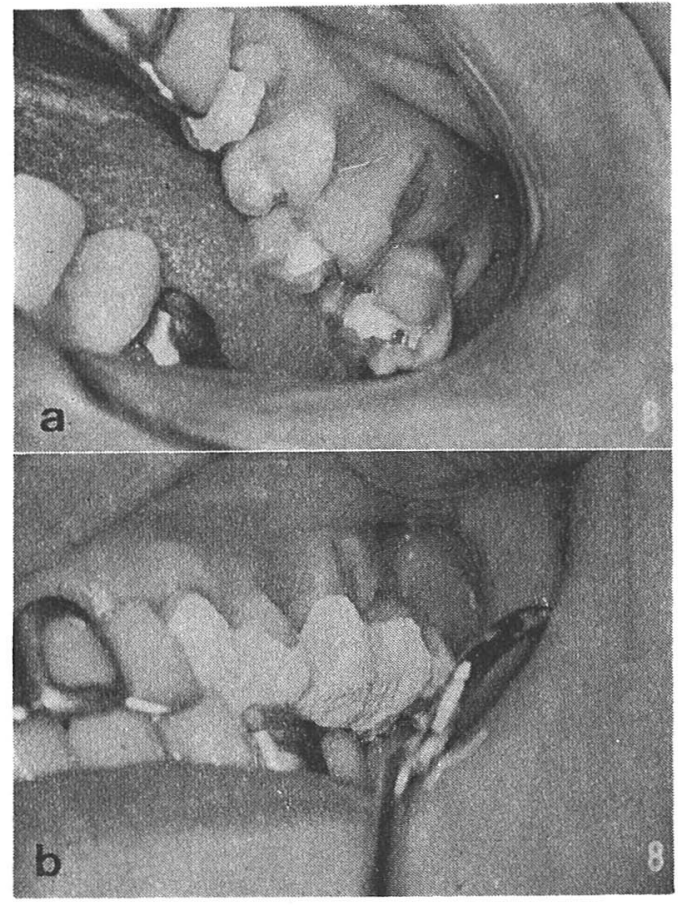

図 7 形成された Coverage Type の窝洞(a)と 形成歯の暫間固定(b)

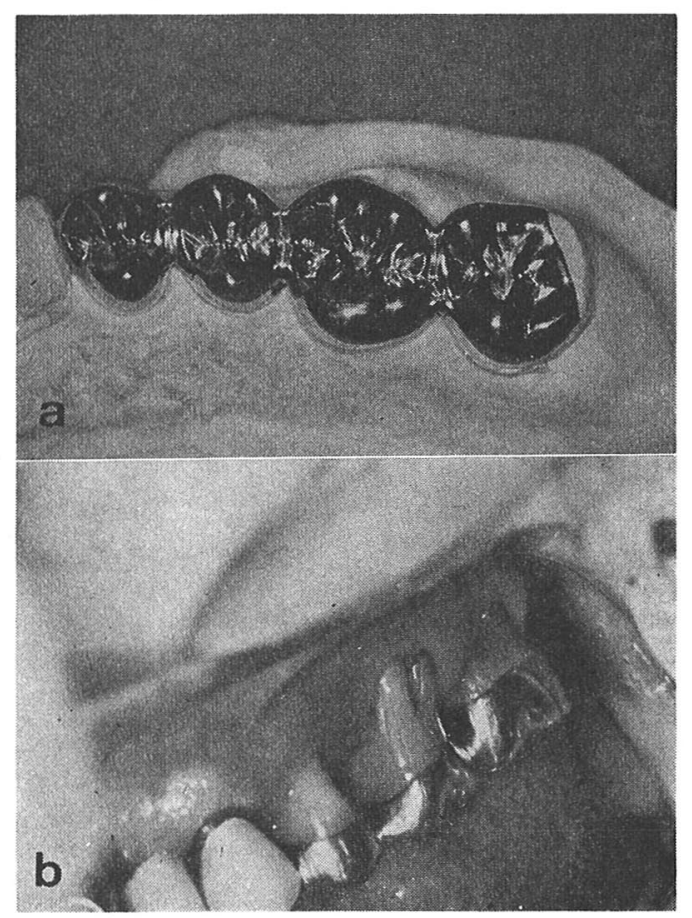

図 8 症例 2 の模型上修復物(a)と口内装着完成(b)

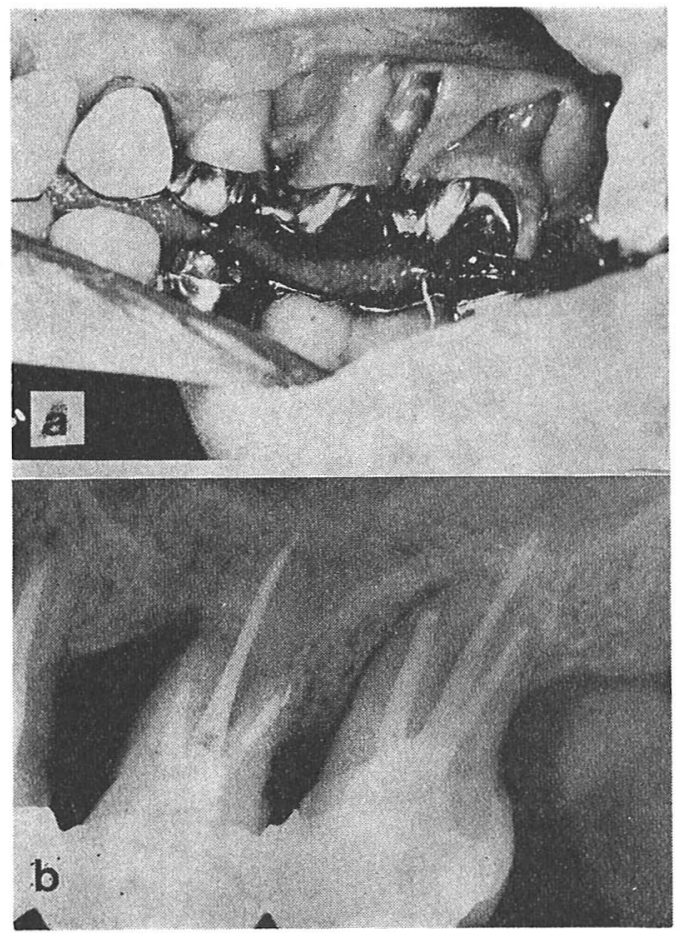

図 9 症例 2 の固定 2 年経過後の口腔内写真(a) とX線写真(b)

固定するのも一法であるう（図 7,b）。

図 8,a は副模型上に置かれた鋳造修復連結物で, 図 8, bのごとく口腔内に装着, 完成された。

固定 2 年経過後の所見

(1) 瀶床的所見 (図 9,a )

歯肉の炎症, 歯肉の形態および付着歯肉の状態は固定 直前の所見と殆ど変らず，固定歯の骨植状態も極めて良 好である。

(2) X線所見 (図 9, b )

16 の歯根全周に亘ってみられた歯根膜腔の拡大はなく なり (歯根膜腔の正常化), さらに舌側根の遠心部では 画槽硬線の再生がみられた。17の近心にみられた垂直性 骨吸収は消失し, 骨の再生がみられた。経過は極めて良 好といえよう。

\section{症例 $3:$, 32歳, 女性}

固定部位 : $\overline{321 / 123}$

\section{固定装置}

前歯部に拔噵，根充処置を施したのちに，保持の強力 な有釘舌面鈑方式を採用した。この際のポストのための 孔の外開き，抽出方向には特に留意する必要がある（図 $10, a ， b)$ 。図 11, a, b は前述と同様型ごと埋没鋳造方 


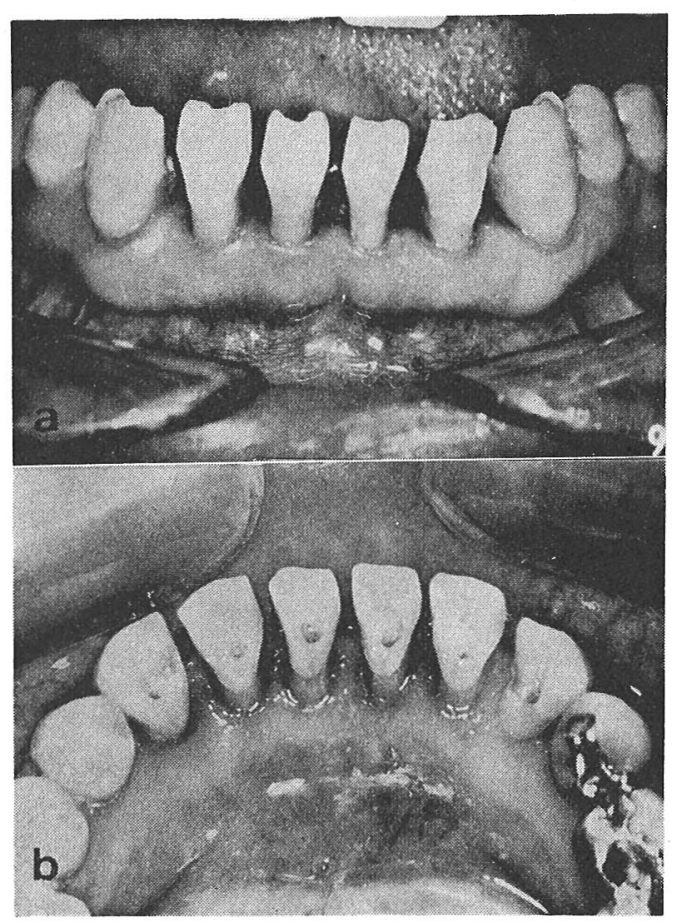

図 10 症例 3 の形成歯の唇面観(a)と舌面観(b)

式で製作された下䫟前歯部の固定装置である。

固定直後の診査

(1) 臨床的所見 (図 11，a，b)

歯肉の炎症は Gingival Index に上れば0〜1の範国 内にあり極めて軽度である。歯肉の形態は歯間部で blunted 型, 辺縁部で recessed 型を示し, ともに退縮 している。歯周ポケットの梁さはすべて $2 \mathrm{~mm}$ 以下で 正常範囲内にある。付着歯肉愊広く $3 \sim 4 \mathrm{~mm}$ を示 す。

\section{(2) X線所見 (図 11, c)}

歯槽骨は 40 50\% の水平性吸収がみられる。歯槽頂 の稀薄化が一部にみられるものの, 歯根膜腔および歯槽 硬線は一応正常像を示している。

固定 1 年経過後の所見

(1) 臨床的所見

歯肉の炎症, 歯肉の形態, 歯周ポケットおよび付着歯 肉は固定直後の所見と殆ど変らない状態を示す（図 12 , a, b)。

(2) X線所見 (図 12, c)

一部にみられた歯槽頂の稀薄化は骨の再生によって明 膫化し, 固定歯周囲の歯根膜腔および歯槽硬線の正常像 と併せて経過は良好といえる。

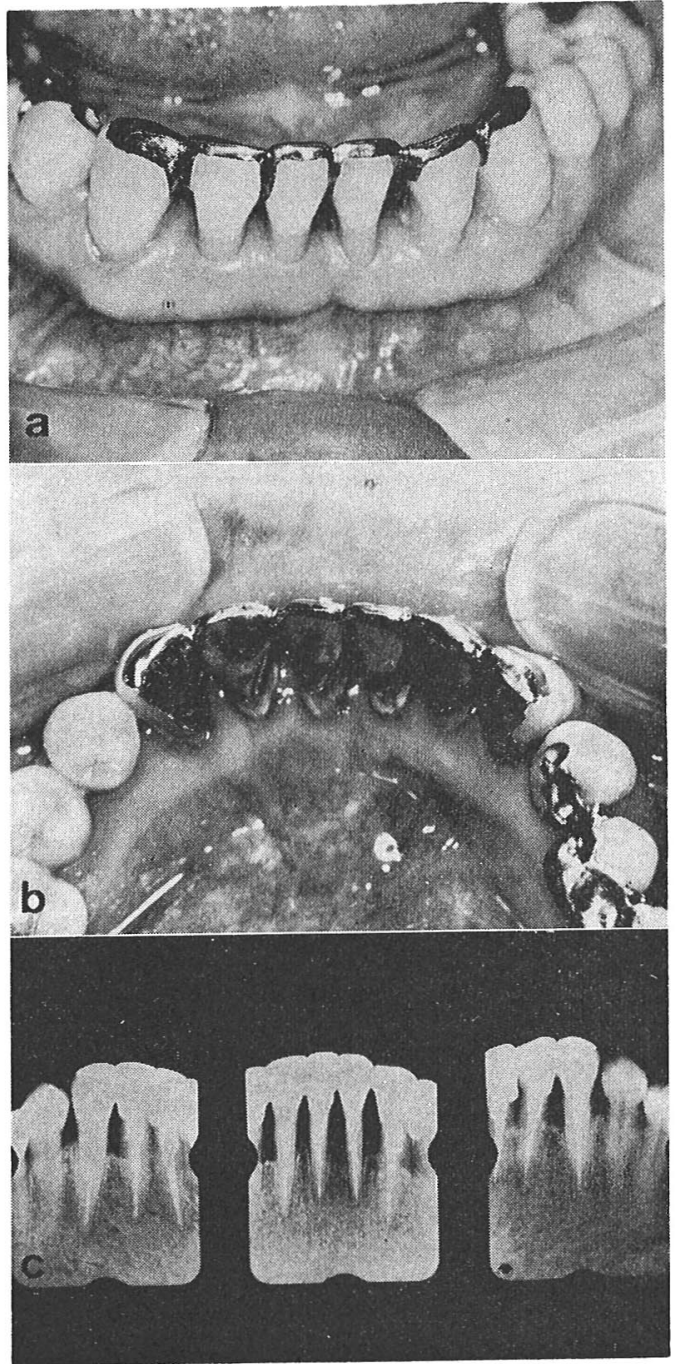

図 11 症例 3 の固定直後の口腔内写真 $(a, b)$ と X線写真(c)

考

察

田中，桜井ら ${ }^{8)} 1956$ 年にすでに型ごと埋没鋳造方 式による前歯部永久固定装置の術式を考案発表してい る。当時は印象材はアルジネートが用いられ, それに注 大される模型材も自家製の石膏量のやや多い鋳造用埋没 材が使用されていたので，広く臨床で行われるには至ら なかった。

1971 年細田7) は試作型ごと埋没材を使っての詳細な 実験を行い，田中らが行っていを方法よりかなり精度の 高いものが得られることが予想されたので，この新型ご 


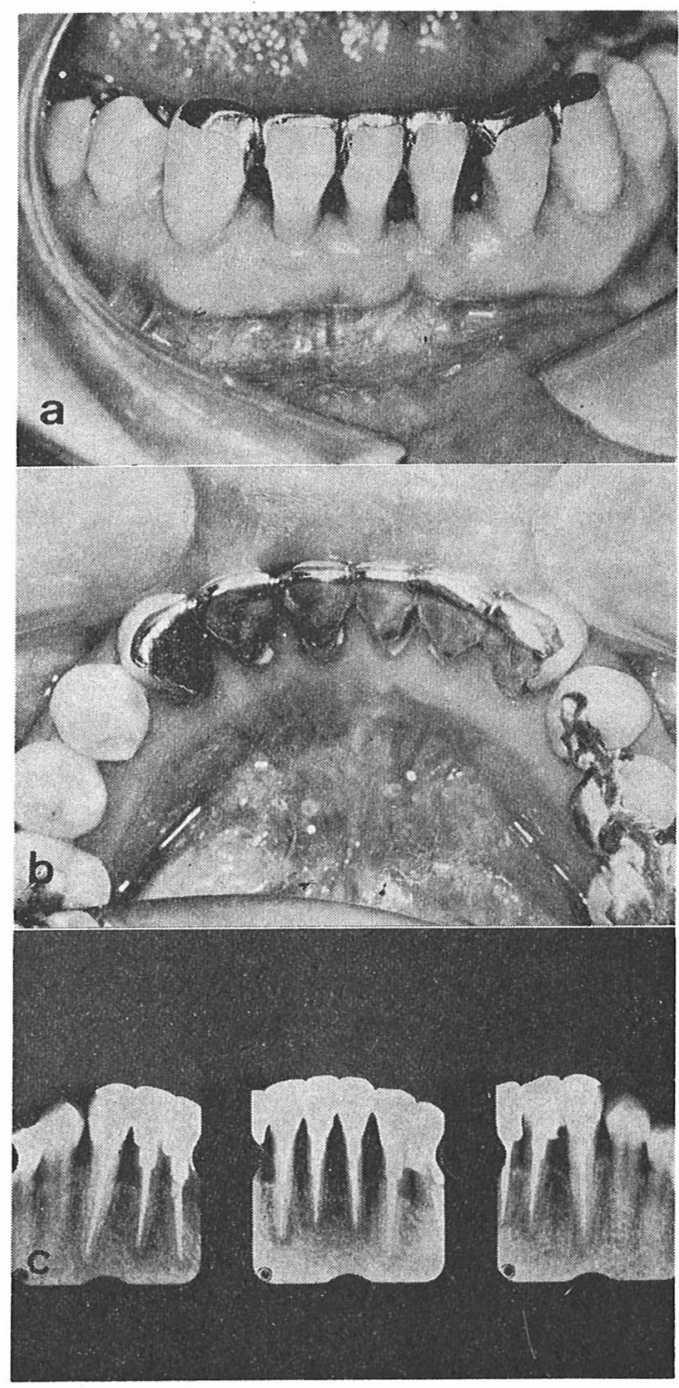

図 12 症例 3 の固定 1 年経過後の口腔内写真 (a, b) とX線写真(c)

と埋没材による動摇歯固定装置への応用を試みたのであ る。

各症例にみられるように, 本型ごと埋没法によって作 られた鋳造連結修復物の臨床的精度は極めて良好であっ た。

型ごと埋没，鋳造法により一塊鋳造連結物を作る場合 には，各䆚洞は通常より少し余分のテーパーが付与さ れ，アンダーカットの存在は少しも許されない。

また, 今回採用した窩洞形態は MOD 型, Coverage 型および有釷舌面鈑等であるが，㸗縁が歯肉に接触する
ことを極力避けるよらその位置は高く設計された。かく することにより歯間は容易に清掃され得て，歯周は清潔 が保持される。

本型ごと埋没法によって，極めて薄い板状連結物まで も簡易にそして狂いの少ない状態で得られるようになっ たことは，臨床に打ける大いなる福音であるといっても 過言ではない。かように技法が簡易化されれば，より多 くの症例に適用されると信じるが，本技法の欠点は模型 が消失してしまうことなので，精度のよい耐火歯型と相 俟って精度のよい副模型の準備についても，考虑が払わ れねばならない。

結論

“型ごと埋没法”による鋳造方式を歯周病動摇歯固定 装置の製作に応用し，これを 3 症例に適用したところ， その適合精度の優秀性とともに病態の改善が確認され た。まだ症例も少ないので，さらに症例数を積み上げな がら種々検討を加えて行きたい。

\section{文献}

1) Rubin, J.G. and Sabella, A.A. : One-piece castings for fixed bridge work, J. Prosthet. Dent. $5: 843,1955$.

2）西村文夫，山口重雄，和久本貞雄 : 各種鑥付法 および一塊鋳造による橋義の精度について，歯 材器誌, $6: 40,1961$.

3) Fusayama, T. : Factors and technique of precision casting; Part I and II, J. Prosthet. Dent. $9: 468,486,1959$.

4）総山孝雄：精密鋳造に関する研究，歯材器誌， $7: 36,1962$

5) Fusayama, T., Hosoda, H. and Wakumoto, S. : A one-piece cast permanent splint, J. Prosthet. Dent. 16 : 572, 1966.

6）真坂信夫：ワンピースキャストブリッジの鋳造 精度に関する研究，歯科学報，70:1，1970。

7）細田裕康：型ごと埋没法に関する一連の研究, 臨床歯科, 268 号, 1971.

8）田中一順, 桜井貞雄 : 歯槽膿漏症前歯部永久固 定の一新法, 口腔科学誌, $5: 2,1956$. 